\title{
PEMBELAJARAN PENDIDIKAN KESEHATAN BERBASIS RISET: ULASAN DAN IMPLEMENTASINYA DI INDONESIA
}

\author{
Kurnia Eka Wijayanti ${ }^{1 *}$, Ricky Wibowo ${ }^{2}$ \\ ${ }^{1}$ Universitas Pendidikan Indonesia \\ email : kurniaeka22@upi.edu
}

\begin{abstract}
Abstrak
Pendidikan kesehatan merupakan salah satu materi yang diajarkan pada pelajaran pendidikan jasmani, olahraga dan kesehatan (PJOK) mulai dari sekolah dasar hingga sekolah menengah atas. Materi yang diberikan beragam dan diberikan disela-sela pembelajaran pendidikan jasmani di setiap semesternya. Adalah penting untuk menjadikan pendidikan kesehatan di dalam PJOK sebagai media untuk meningkatkan literasi mengenai kesehatan di Indonesia. Pendidikan kesehatan juga harus bisa menjadi bagian dari solusi bagi permasalahan kesehatan di Indonesia. Oleh sebab itu, pendidikan kesehatan harus dirancang berbasis riset, baik dari segi materi maupun metode penyampaiannya. Di Indonesia hal ini dapat dikatakan baru, akan tetapi kita dapat belajar dari profesi lain dan dari negara lain bagaimana mempersiapkan dan memulai pembelajaran pendidikan kesehatan berbasis riset.
\end{abstract}

Kata kunci: Pendidikan Kesehatan, Promosi Kesehatan, Promosi Kesehatan

\begin{abstract}
Health education is one of the materials taught in physical education subject starting from primary schools to secondary schools. In this subject, the materials are given variously and in between hours of physical education subject in every semester. It is important to make health education learning media to improve health literacy in Indonesia. Health education should be able to solve problems in relation to health as well. Therefore, health education needs to be a research-based subject, either in terms of its materials or its method. In Indonesia, integrating a researchbased subject is schools in something new; however, other professions and other countries have succeeded to do so that it is such a good thing to adapt.
\end{abstract}

Keywords: Health Education, Research-Based Education, Health Promotion.

\section{PENDAHULUAN}

Terdapat 4 aspek pelayanan kesehatan dasar, yaitu promotif, preventif, kuratif dan rehabilitatif. Keempat aspek tersebut sama-sama memiliki peran yang penting dalam meningkatkan derajat kesehatan masyarakat. Pendidikan, merupakan aspek yang dapat diletakkan di semua lini pelayanan kesehatan dan dapat membantu supaya setiap aspek dapat berjalan dengan baik. Di lini promotif, pendidikan kesehatan berperan meningkatkan dan menjaga derajat kesehatan pada orang yang berada dalam kondisi sehat, seperti menjaga pola makan yang baik atau perencanaan sanitasi yang tepat. Pada aspek preventif, melalui pendidikan kesehatan, masyarakat diharapkan dapat melakukan programprogram kesehatan yang mencegah mereka dari penyakit, misalnya saja dengan melakukan vaksinasi. Pada aspek kuratif, masyarakat yang terdidik diharapkan mampu mengenali kondisi yang sakit dan dapat mencari tempat pengobatan yang sesuai sehingga diharapkan dapat memperpendek masa sakit 
dan mencegah disabilitas. Yang terakhir, pendidikan dalam aspek rehabilitasi diharapkan dapat membuat masyarakat mengetahui bahwa disabilitas yang terjadi akibat suatu penyakit dapat dibatasi dan kemampuan yang ada ketika sebelum sakit dapat dikembalikan dengan melakukan program rehabilitasi.

Pendidikan kesehatan yang dilakukan di sekolah-sekolah bertujuan mendukung aspek promosi kesehatan dan menitikberatkan pada perubahan perilaku. Dengan adanya pendidikan, maka diharapkan masyarakat menjadi mampu dan mau mengontrol perilakunya sehingga dapat meningkatkan derajat kesehatannya. (Ottawa charter 1986, WHO). Deklarasi Jakarta tahun 1997 pun menjadikan bagian peningkatan literasi kesehatan sebagai aspek yang penting dan semakin menegaskan peranan pendidikan kesehatan. Pendidikan kesehatan bukan saja dapat meningkatkan pengetahuan, akan tetapi juga dapat mengembangkan keterampilan-keterampilan yang berguna bagi individu dan masyarakat(Nutbeam, 1998). Perubahan perilaku yang diharapkan dapat terjadi sebagai hasil dari pendidikan kesehatan, merupakan hasil dari kolaborasi beberapa bidang studi seperti psikologi, antropologi, sosiologi, pendidikan, komunikasi dan manajemen.

\section{METODE}

Apakah yang dimaksud dengan pembelajaran berbasis riset? Pembelajaran berbasis riset (PBR) merupakan salah satu metode student-centered learning (SCL) yang menggabungkan riset di dalam proses pembelajaran. (PUPBR, 2010). PBR memberi keleluasaan / kesempatan kepada mahasiswa untuk menggali informasi, menyusun hipotesis, mengumpulkan data, menganalisis data, dan membuat kesimpulan atas data yang sudah tersusun. Dalam proses ini pembelajaran dilakukan dengan pendekatan "learning by doing". Dengan PBR akan terbuka peluang bagi pengembangan metode pembelajaran, antara lain: 1. pembaharuan bahan pembelajaran (pengayaan kurikulum) dengan mengintegrasikan hasil riset, 2. Peran serta aktif mahasiswa di dalam pelaksanaan riset, 3 . pembelajaran dengan mempergunakan instrumen riset, dan 4. pengembangan konteks riset secara inklusif (mahasiswa mempelajari prosedur dan hasil riset untuk memahami seluk-beluk sintesis). Berdasarkan pemaparan diatas, maka yang akan dibahas khusus pada tulisan ini yaitu pembaharuan pembelajaran (pengayaan kurikulum) dengan mengintegrasikan hasil riset, dan pembelajaran dengan menggunakan instrumen riset.

Seperti telah dijelaskan sebelumnya, pendidikan kesehatan merupakan bagian dari solusi terhadap masalah-masalah kesehatan yang ada di masyarakat. Ini artinya, masalah yang dimasukkan ke dalam kurikulum harus sesuai dengan apa yang ada di masyarakat pada saat itu. Apa yang menjadi masalah 10 tahun yang lalu, belum tentu masih menjadi masalah saat ini. Begitu juga sebaliknya, apa yang beberapa dekade lalu bukan merupakan suatu hal yang harus dirisaukan, bisa jadi sekarang merupakan masalah yang harus dipikirkan jalan keluarnya secara serius.

Contoh yang bisa diambil misalnya adalah masalah rokok. Data Kementerian Kesehatan memberikan gambaran kenaikan prevalensi perokok dari $27 \%$ pada tahun 1995, menjadi 36,3\% pada tahun 2013. Prevalensi perokok perempuanpun ikut meningkat dari 4,2\% pada tahun 1995 menjadi 6,7\% pada tahun 2013. Selain itu, prevalensi remaja usia 16-19 tahun yang merokok jug meningkat 3 kali lipat dari 7,1\% di tahun 1995 menjadi 20,5\% pada tahun 2014. Usia perokok pun semakin hari semakin muda. Perokok dengan usia 10-14 tahun mengalami keningkatan lebih dari 100\% dalam hanya kurun waktu kurang dari 20 tahun, yaitu dari 8,9\% di tahun 1995 menjadi 18\% di tahun 2013. (Riskesdas 2013). Ini berarti, masalah ini masih menjadi topik yang harus dimasukkan kedalam kurikulum pendidikan kesehatan, bahkan mungkin kepada siswa dengan usia lebih muda. 
Contoh lain adalah masalah infeksi menular seksual yang terus meningkat di masyarakat, terutama kalangan remaja. Pada tahun 2011 terdapat kenaikan angka kejadian baru pada infeksi gonore dan klamidia sebanyak 179\% dan sifilis sebanyak 44\%. Kasus HIV juga meningkat dari 859 kasus di tahun 2005 menjadi 21.511 kasus pada tahun 2012. Penderita yang jatuh kedalam kondisi AIDS pun meningkat dari 2.639 kasus di tahun 2005 menjadi 5.686 di tahun 2012. (http://www.depkes.go.id). Infeksi menular seksual tersebut dapat terjadi karena adanya perilaku seks tidak aman yang dipraktekkan oleh remaja usia sekolah. Perilaku sesk tidak aman tersebut juga akan mengarah kepada kehamilan yang tidak diinginkan dan sebagian membuat mereka melakukan tindakan aborsi yang tidak aman. Utomo et al. (2001) memperkirakan ada sekitar 2 juta aborsi pertahun di Indonesia, dengan rasio 43 aborsi per 100 kelahiran hidup atau 30\% dari seluruh kehamilan. Perempuan yang melakukan aborsi biasanya berusia 20 tahun atau lebih (92\%) dan insidensi aborsi lebih tinggi pada daerah suburban (60\%) daripada di kota (30\%). Hull and Hartanto (2009) memperkirakan aborsi yang dilakukan oleh perempuan dengan usia dibawah 19 tahun adalah sebanyak $10 \%$ dan wanita tidak menikah sebanyak 33\%. Persentasi perempuan berusia dibawah 19 tahun yang melakukan tindakan aborsi tidak aman diperkirakan lebih banyak dan biasanya lebih banyak di daerah pedesaan (Sedgh and Ball 2008). Masalah-masalah tersebut diatas, dapat dikurangi apabila remaja sudah mendapatkan materi pendidikan seks dan tahu bahwa penggunaan kondom bisa mengurangi risiko penularan infeksi menular seksual (King et all, 2004).

Masalah kesehatan lain yang juga tidak kalah pentingnya adalah jumlah siswa usia sekolah dengan obesitas yang terus meningkat. Angka obesitas pada anak usia 6-15 tahun meningkat dari 5\% tahun 1990 menjadi 16\% tahun 2001 (Soegondo, 2008). Kenaikan angka obesitas juga terjadi sejak usia sangat dini. Angka obesitas meningkat 2 (dua) kali lipat pada anak usia 2-5 tahun dan usia 12-19 tahun, bahkan meningkat tiga (3) kali lipat pada anak usia 6-11 tahun, apabila dibandingkan dengan angka pada tahun 1970. Padahal anak dengan obesitas akan memiliki risiko lebih tinggi untuk terkena penyakit-penyakit sistemik seperti hipertensi, diabetes mellitus ataupun penyakit jantung coroner (Pulgaron, 2013). Sistem pendidikan di negara-negara lain sudah berhasil meningkatkan literasi dan awareness masyarakat terhadap penyakit-penyakit sistemik tidak menular ini, sehingga masyarakat lebih peduli dan punya keinginan untuk merubah pola makan dan gaya hidupnya ( Walter et all, 2006). Selain pengayaan kurikulum yang disusun berbasis riset, pembelajaran dilakukan dengan menggunakan instrumen riset. Pengajaran berbasis riset merupakan metode yang berdasarkan kepada hasil penelitian- hasil penelitian terbaru yang terpercaya. Terdapat beberapa strategi dalam memadukan pembelajaran dan riset yang secara empirik dikembangkan di Griffith University yaitu : 1) Memperkaya bahan ajar dengan menggunakan hasil penelitian dosen ; 2) Menggunakan temuantemuan penelitian mutakhir dan melacak sejarah ditemukannya perkembangan mutakhir tersebut ; 3) Memperkaya kegiatan pembelajaran dengan menambah isu-isu penelitian kontemporer ; 4) Mengajarkan materi mengenai metodologi penelitian di dalam proses pembelajaran ; 5) Memperkaya proses pembelajaran dengan cara melakuakn kegiatan penelitian dalam skala kecil ; 6) Memperkaya proses pembelajaran dengan cara melibatkan peserta didik dalam kegiatan penelitian institusi ; 7) Memperkaya proses pembelajaran dengan cara mendorong peserta didik supaya mereka merasa menjadi bagian dari budaya penelitian di fakultas/jurusan; 8) Memperkaya proses pembelajaran dengan memasukkan nilai-nilai yang harus dimiliki oleh peneliti.

Perlu juga dipertimbangkan hasil-hasil penelitian lintas sektor yang dapat turut menunjang keberhasilan pembelajaran pendidikan kesehatan. Sebagai contoh, adanya pengaruh kultur dalam pelaksanaan program intervensi kesehatan (Collins et all, 2014). Di dalam penelitian itu, ternyata stigma yang berhubungan dengan obesitas, Human Immunideficiency Virus (HIV) dan Acquired 
Immune Deficiency Syndrome (AIDS) tidak terlepas dari kultur yang diterima di suatu tempat. Pada tempat tertentu, dikatakan adanya kultur memiliki porsi makan yang besar dan semakin tergerusnya tempat membeli makan yang sehat di lingkungan perumahan membuat semakin sulit untuk menurunkan angka obesitas. (Airhihenbuwa, 2010), Morland, Wing \&diez Rouz, 2002). Selain itu, dalam satu dekade terakhir telah banyak hasil penelitian yang mengungkapkan betapa stigma telah turut serta dalam penyebaran, deteksi, dan penatalaksanaan infeksi HIV.(Herek et all,2003, Kinsler et all 2007, Petros et all 2006, Poindexter 2010). Stigma didiskusikan menjadi bagian dari komponen dan proses yang terhubung dengan nilai-nilai normatif (Link \&Phelan (2006). Lebih lanjut, kultur juga menjadi bagian penting dalam penyusunan kurikulum berbasis riset (Lipka, J et all, 2005, Nijhuis.C.J.G,2013).

\section{HASIL DAN PEMBAHASAN}

Penerapan praktek berbasis riset pada beberapa profesi telah dilakukan sejak tahun 1990an, seperti misalnya pada profesi kedokteran dan psikologi. Penerapan hasil riset didalam bidang pendidikan sendiri dapat dikatakan tertinggal (Hempenstall, 2006). Belajar dari negara-negara lain, Indonesia dapat memulai dengan cara meningkatkan kepedulian terhadap pendidikan kesehatan berbasis riset dan membentuk gerakan yang diharapkan dapat membawa perubahan yang memberikan hasil signifikan.

Pergerakan pertama yang tercatat muncul di Amerika Serikat, yaitu Reading Excellence Act (the Omnibus Appropriations Bill, 1998), yang merupakan respon terhadap ketidakpuasan masyarakat akan pencapaian kemampuan membaca di Amerika Serikat. Hal ini ternyata disebabkan oleh metode instruksi membaca yang sedang diberlakukan saat itu, dan kebijakan literasi yang tidak menunjang perkembangan dalam memahami proses membaca. Para penggagas aksi tersebut berhasil menghubungkan penelitian dengan ruang belajar dengan cara hanya menerapkan 5 program membaca yang terbukti efektiflah yang dapat menerima pendanaan dari pemerintah. Pendanaanpun akhirnya hanya diberikan kepada program-program yang terbukti efektif berdasarkan hasil riset yang terpercaya dan dilakukan berulang-ulang.

Di Inggris, kekhawatiran yang sama akhirnya menghasilkan Strategi Literasi Nasional / National Literacy Strategy (Departement for Education and Employment, 1998) yang memberikan mandat bahwa pendekatan-pendekatan pengajaran harus berdasarkan hasil riset. Pada awal pelaksanaannya, dekrit ini mendapat penolakan dari dunia pendidikan dan tujuan yang direncanakan tidak tercapai. Pendekatan baru lalu dilegalkan sebagai Primary National Strategy pada tahun 2006.

Di Australia, The National Enquiry into the Teaching of Literacy (2005) juga menyimpulkan hal yang sama mengenai peran penting riset pendidikan. Ulasan pemerintah Australia mengenai pembiayaan untuk panel sekolah ( Funding for Schooling Panel (2011)) menyimpulkan kurangnya hasil riset dalam pelaksanaan program pendidikan dan tidak adanya evaluasi program terhadap pembelajaran. (Nous Group, 2011). The National Research Council's Center for Education (Towne, 2002) menyarankan bahwa pendidik harus melakukan riset yang (a) memiliki pertanyaan signifikan yang bisa diteliti secara empiris ; (b) menghubungkan antara penelitian dengan teori ; (c) menggunakan metode yang memungkinkan penelitian langsung yang menjawab pertanyaan penelitian; (d) menyediakan hubungan koheren terhadap alasan yang kuat; (e) replikasi dan generalisasi; dan (f) memastikan transparansi . Tujuan dari konsil ini adalah untuk meningkatkan kualitas jurnal pendidikan, dan menegaskan kembali hubungan antara penelitian berbasis sains dan praktek pendidikan. Luarannya diharapkan dapat 
berperan dalam pembuatan kebijakan pendidikan, seperti yang terjadi pada profesi kedokteran (Shavelson \& Towne, 2002).

Pada era digital seperti saat ini, ada media yang dapat dimanfaatkan untuk menghimpun informasi dan menyebarkannya kepada semua pihak yang berkecimpung di dalamnya, yaitu internet. Salah satu contoh yang dapat dilihat adalah ectacenter.org. Website ini berada di bawah pengelolaan University of North Carolina, dan menyediakan infrormasi bagi pelaksanaan praktik pendidikan berbasis riset dibidang pendidikan anak usia dini. Di dalam laman website tersebut terdapat informasi mulai dari definisi mengenai praktik pendidikan berbasis bukti, sistem pembelajaran, implementasi, sampai dengan hasil-hasil penelitian terbaru yang dapat mendukung pelaksanaan praktik pendidikan berbasis riset. Hal seperti ini sangat beguna apabila dilakukan di Indonesia, mengingat negara Indonesia memiliki kawasan yang luas dan masih terdapat kendala trasportasi di beberapa daerah. Dengan adanya panduan seperti ini, maka siapapun yang berasal dari manapun dapat mengakses informasi yang ada didalamnya, sehingga diharapkan dapat mempercepat pelaksanaan praktik pendidikan berbasis riset.

Hal berikutnya yang menjadi pertimbangan dan harus dipersiapkan adalah menyediakan hasil-hasil riset yang menjadi landasan dan mendukung praktik pendidikan berbasis riset. Hal ini menjadi penting, mengingat ternyata pertimbangan kultur memiliki peranan dalam penyusunan pengayaan materi dan proses pembelajaran. Oleh sebab itu, riset-riset yang dijadikan rujukan bukan hanya berasal dari luar negeri, tetapi juga dari dalam negeri. Secara umum, penelitian-penelitian mengenai pendidikan, terutama pendidikan kesehatan dimasa lampau belum dapat dikatakan berkualitas dan memuaskan. Ini berimbas kepada kesulitan untuk mengevalusi dan mempergunakan hasil riset bagi penyusunan pengayaan kurikulum dan pembelajaran Ditambah lagi, banyak pengajar yang tidak dilatih untuk menelaah desain dan hasil-hasil penelitian. Harus diakui, alokasi dana riset di Indonesia masih kalah dibandingkan dengan dana riset di negara lain. Berdasarkan data yang dihimpun oleh Kementerian Riset, Teknologi, dan Pendidikan Tingggi, dana riset Indonesia merupakan yang terendah di kawasan ASEAN. Di antara negara-negara di seluruh dunia, Korea Selatan adalah negara dengan dana riset tertinggi yaitu sebesar 4,3 persen PDB, diikuti Israel (4,1 persen PDB), dan Jepang (3,6 persen PDB) (Ristekdikti, 2016). Sedangkan untuk kawaasan ASEAN, Malaysia tercatat mengeluarkan dana belanja R\&D (penelitian dan pengembangan) sebesar 1,13 persen (2014), Thailand 0,39 persen (2014), bahkan Singapura sudah 3,174 persen (2014), sedangkan di Indonesia hingga tahun 2016 anggaran belanja R\&D hanya menghabiskan 0,2 persen dari dana pemerintah. Padahal, riset-riset yang berhubungan dengan pendidikan terutama pendidikan kesehatan meliputi penelitianpenelitian perilaku dan social science yang tidak jarang memerlukan waktu lama dan perlu kesinambungan dalam pelaksanannya. Oleh sebab itu, diharapkan kedepannya pemerintah dapat meningkatkan dana riset sehingga dapat menunjang peningkatan mutu pembelajaran.

Hal terakhir yang paling penting adalah mempersiapkan para pendidik untuk dapat melakukan praktik pendidikan berbasis bukti. Pendidikan tersebut terbagi menjadi dua, yaitu pendidikan di institusi perguruan tinggi, dan pendidikan berkelanjutan setelah siswa lulus dan bekerja. Perkuliahan dirancang untuk dapat mengajarkan strategi belajar yang efektif, dan berdasarkan pada hasil riset terbaru. Salah satu contoh nya adalah penelitian yang dilakukan Slameto dkk pada tahun 2016. Penelitian ini berhasil menemukan Model Pembelajaran Berbasis Riset di Prodi Pendidikan Guru Sekolah Dasar yang dinilai layak dan mampu meningkatkan hasil belajar mahasiswa. (Slameto, dkk . 2016). Selain itu, pendidikan berkelanjutan perlu juga diberikan pagi para pendidik supaya mereka tetap mendapat hasil-hasil riset terkini yang dapat diaplikasikan dalam praktek pengajaran di dalam kelas. 


\section{KESIMPULAN}

Pelaksanaan pembelajaran pendidikan kesehatan berbasis riset di Indonesia memang masih berada dalam tahap awal. Keberhasilannyapun tergantung dari berbagai pihak. Yang dapat dilakukan saat ini adalah komitmen dari institusi pencetak guru untuk mulai memasukkan unsur riset dan sekaligus membekali para muridnya dengan kemampuan untuk menganalisa, memilih dan menggunakan hasilhasil riset yang sesuai, dan juga komitmen pemerintah dalam bentuk kenaikan anggaran riset.

\section{DAFTAR PUSTAKA}

Airhihenbuwa.C.O (2010). Culture Matters in Global Health. European Health Psychologist. 12,52-55 A Guide to Evidence Based program for Adolescent Health: Programs, tools, and More.(2014) The National Adolescent and Young Adult Health Information Center Presents. University of California San Fransisco. 2014

Clark BR., 1997, The Modern Integration of Research Activities with Teaching and Learning, J. Higher Educ., 1997; 68:241-255

Dana Riset Indonesia Paling Rendah di Asia Tenggara (2017) (Online). Diunduh dari https://tirto.id/dana-riset-indonesia-paling-rendah-di-asia-tenggara-chUP

Dana Riset Jadi 0,2 Persen PDB, tetapi Cuma karena Perubahan Rumus Penghitungan (Online). Diunduhdarihttp://amp.kompas.com/sains/read/2016/09/15/20481681/dana.riset.jadi.0.2.persen .pdb.tetapi.cuma.karena.perubahan.rumus.penghitungan

Deklarasi Jakarta tentang Promosi Kesehatan pada Abad 21(Online) Diungguh dari http://perpustakaan.litbang.depkes.go.id/otomasi/index.php?p=show detail\&id=5781

Griffith Institute for Higher Education, 2008, Research-based learning: strategies for successfully linking teaching and research. University of Griffith.

Herek, G.M, Capitano,J.P \& Widaman, K.F (2003). Stigma, social risk and health policy: Public attitudes toward HIV surveillance policies and the social construction of illness. Health Psychology, 22, 533-540.

Hull, Terence $\mathrm{H}$ and Wendy Hartanto. 2009. "Resolving contradictions in Indonesian fertility estimates." Bulletin of Indonesian Economic Studies 45:61-71.

Holmes ,K. Levine, R. Weaver, M.(2004). Effectiveness of condoms in preventing sexually transmitted infections. Bulletin of the World Health Organization. 2004 http://ectacenter.org/topics/evbased/evbased.asp

Kinsler,J.J., Wong,M.D., Sayles,J.N..,Davis,C., \& Cunningham, W.E.(2007). The effect of perceived stigma from a health care provider on access to care among a low income HIV-positive population. AIDS Patient Care STDS, 21,584-592.

Lipka, J. et all (2005). The Relevance of Culturally Based Curriculum and Instruction: The Case of Nancy Sharp. Journal of American Indian Education - Volume 44, Issue 3,31-54

Link, B. G., \& Phelan, J. C. (2006). Stigma and its public health implications. Lancet, 367, 528-529.

Morland,K. Wing,S., \& Diez Roux,A. (2002). The Contextual effect of the local food environment on residents diet: The atherosclerosis risk in community study. American Journal of Public Health,92,1761-1767

Nijhuis, C.J.G (2013). Influence of culture on curriculum development in Ghana: an undervalued factor?. Journal of Curricullum Studies. Volume 45, 2013. Issue 2.

Nous Group Consortium. (2011). Schooling challenges and opportunities: A report for the Review of Funding for Schooling Panel. Nous Group Consortium, August 29. Retrieved from 22

Nutbeam D (1998) Health promotion glossary. Health Promotion International: V 0113. no. 4. Oxford University Press. 
Pedoman Umum Pembelajaran Berbasis Riset (PUPBR). Universitas Gajah Mada. 2010.

Petros, G., Airhihenbuwa,C.O., Simbayi, L.,Ramlagan,S.,\& Brown,B.(2006). HIV positive women: Perceptions of stigma in healthcare settingin Western Cape, South Africa. Healthcare for Women International. Advance online publication. Doi:10.1080/07399332.2012.736566

Poindexter, C. C., \& Shippy, R. A. (2010). HIV diagnosis disclosure: Stigma management and stigma resistance. Journal of Gerontological Social Work, 53, 366-381.

Pulgaron. E. Childhood Obesity: A Review of Increased Risk for Physical and Psychological Comorbidities. Clin Ther. 2013 January ; 35(1): A18-A32

Riset Kesehatan Dasar 2013 (Riskesdas 2013)(Online) Diunduh dari http://www.depkes.go.id/resources/download/general/Hasil\%20Riskesdas\%202013.pdf

Sedgh, G and H Ball. 2008. "Abortion in Indonesia." Guttmacher Institute, New York.

Shavelson, R. J., \& Towne, L. (Eds.). (2002). Scientific research in education. Washington, DC: National Academy Press

Slameto, Wardani,N.S; Kristin,F. Pengembangan Model Pembelajaran Berbasis Riset Untuk Meningkatkan Keterampilan Berpikir Aras Tinggi. Prosiding Konser Karya Ilmiah Nasional Vol. 2, Agustus 2016 | ISSN: 2460-5506

Soegondo, Sidartawan. Berbagai Penyakit dan Dampaknya terhadap Kesehatan dan Ekonomi. Widyakarya Nasional Pangan dan Gizi (WNPG) IX. Jakarta, 2008.

The Ottawa Charter for Health Promotion 1986. (Online) Diungguh dari http://www.who.int/healthpromotion/conferences/previous/ottawa/en/index4.html

Utomo, B., V. Hakim, A.H. Habsyah, Irwanto, L. Tampubolon, D.N. Wirawan, S. Jatiputra, K.N. Siregar, L.H. Tarigan, B. Affandi, and Z. Tafal. 2001. "Incidence and Social-Psychological Aspects of Abortion in Indonesia: A Community-Based Survey in 10 Major Cities and 6 Districts, Year 2000.” Center for Health Research University of Indonesia, Jakarta.

Utomo I.D, Utomo.A. Adolescent Pregnancy in Indonesia: A Literature Review. World Population Day 2013. Australian Demographic and Social Research Institute The Australian National University. 2013

Walter C. Willett, Jeffrey P. Koplan, Rachel Nugent, Courtenay Dusenbury, Pekka Puska, and Thomas A. Gaziano. Prevention of Chronic Disease by Means of Diet and Lifestyle Changes. Disease Control Priorities in Developing Countries. 2nd edition. 2006 